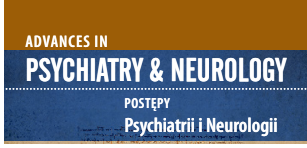

Correspondence to/

Adres do korespondencji:

Małgorzata Wiszniewska Szpital Specjalistyczny im. Stanisława Staszica w Pile ul. Rydygiera 1 64-920 Piła

tel.: 48605564391

faks: 48672106440

e-mail:mpwisz@gmail.com

Submitted/Otrzymano: 27.09.2017

Accepted/Przyjęto do druku: 26.11.2017

\section{THE POSITIVE EFFECT OF COMBINED TREATMENT WITH THROMBOLYSIS AND NEUROSURGERY FOR CERVICAL MYELOPATHY DUE TO ANTERIOR SPINAL ARTERY THROMBOSIS KORZYSTNY EFEKT SKOJARZONEGO LECZENIA TROMBOLITYCZNEGO I NEUROCHIRURGICZNEGO MIELOPATII SZYJNEJ Z POWODU ZAKRZEPU TĘTNICY RDZENIOWEJ PRZEDNIEJ}

\author{
Małgorzata Wiszniewska', Marek Harał² \\ 'Department of Neurology and Stroke Unit, Hospital in Piła, Piła, Poland \\ ${ }^{2} 10^{\text {th }}$ Military Research Hospital and Polyclinic, Bydgoszcz, Poland \\ 'Oddział Neurologii z Pododdziałem Leczenia Udarów, Szpital Specjalistyczny \\ im. Stanisława Staszica, Piła, Polska \\ ${ }^{2}$ Klinika Neurochirurgii, 10 Szpital Wojskowy, Bydgoszcz, Polska
}

\begin{abstract}
Purpose: Vascular-related spinal cord injury accounts for 5.8\% cases of acute myelopathy, whereas spinal cord ischemia is identified 100 times less often than a cerebral stroke. Ischemic myelopathy can also occur due to mechanical compression exerted by an osteophyte on the anterior spinal artery. So far there have been no clear guidelines for the management of such a patient. It seems that a recombinant tissue plasminogen activator (rtPA) could be used in the treatment. The available literature reports one paraplegic patient with thoracic spinal cord ischemia, who had been treated with rt-PA with a moderately favourable outcome.

Case description: We present a case of a patient with cervical spinal cord ischemia, whose paresis resolved almost completely after having received combined treatment with thrombolysis and neurosurgery.

Comment: We would like to emphasise that in spinal cord ischemia, and also if it is caused by mechanical compression of osteophyte on the artery, intravenous thrombolysis before surgery can prevent complete spinal cord infarction. The possibility to administer rt-PA in treating spinal cord ischemia should be included in the guidelines for the management of ischemic stroke. Close cooperation between neurologist and neurosurgeon is necessary to provide combined treatment promptly.
\end{abstract}

Key words: ischemic myelopathy, rt-PA, neurosurgery.

\title{
Streszczenie
}

Cel: Do mielopatii niedokrwiennej może dojść w przypadku ucisku tętnicy rdzeniowej przedniej przez wyrośl kostną. W dotychczasowej literaturze opisano jednego pacjenta z niedokrwieniem rdzenia piersiowego, u którego po dożylnym podaniu rekombinowanego tkankowego aktywatora plazminogenu (recombined tissue plasminogen activator - rt-PA) nastąpiła poprawa. Celem pracy jest przedstawienie pacjenta $\mathrm{z}$ niedokrwieniem rdzenia szyjnego, u którego nastąpiło prawie całkowite ustąpienie niedowładu po skojarzonym dożylnym leczeniu trombolitycznym rt-PA z zabiegiem neurochirurgicznym.

Opis przypadku: Chory, 61 lat, bez czynników ryzyka, uprawiający sport, został przyjęty z powodu osłabienia kończyn prawych. Rozpoznano niedokrwienie rdzenia szyjnego na poziomie C5-6 i zastosowano dożylnie rt-PA z następczą operacją neurochirurgiczną. Niedowład ustąpił. 
The positive effect of combined treatment with thrombolysis and neurosurgery for cervical myelopathy due to anterior spinal artery thrombosis Korzystny efekt skojarzonego leczenia trombolitycznego i neurochirurgicznego mielopatii szyjnej z powodu zakrzepu tętnicy rdzeniowej przedniej

Komentarz: W niedokrwieniu rdzenia kręgowego wywołanym przez mechaniczny ucisk tętnicy przez wyrośl kostną dożylna tromboliza przed zabiegiem chirurgicznym może ochronić rdzeń kręgowy przed pełnym zawałem. W wytycznych dotyczących leczenia udaru niedokrwiennego warto zaznaczyć, że rt-PA może przynieść korzyść także w niedokrwieniu rdzenia kręgowego.

Słowa kluczowe: niedokrwienna mielopatia, rt-PA, leczenie neurochirurgiczne.

\section{PURPOSE}

Vascular-related spinal cord injury accounts for 5.8\% cases of acute myelopathy and about $1.2 \%$ cases of strokes, whereas spinal cord ischemia is identified 100 times less often than cerebral stroke [1]. Many stroke triggers may cause spinal cord ischemia, such as atherosclerosis, systemic hypotension, cardiogenic embolism, aortic dissection, systemic connective tissue disorders, vasculitis, or thrombophilia [1-5]. Ischemic myelopathy can also occur due to mechanical compression exerted by spondylosis-related osteophytes on the anterior spinal artery [3-5]. Spinal cord ischemia develops when an additional mechanical stimulus is involved, such as sudden movement, physical exertion or injury $[5,6]$. In such cases, neurological deficits (paresis affecting one or more limbs) are accompanied by radiculalgia $[6,7]$. Patients with spinal cord ischemia/stroke need immediate hospitalisation; however, there are no clear guidelines for their management [1]. A patient diagnosed with spinal cord ischemia receives general treatment and antiplatelet drugs, nevertheless, in most described cases heparin therapy has been used, with variable success [1-3]. It seems that in the case of spinal cord ischemia the administration of thrombolysis within an adequate time window may prevent permanent spinal cord dysfunction [8]. So far there has been one such case described: an 81-year-old paraplegic patient with thoracic spinal cord ischemia who had been treated with intravenous thrombolysis, after which his functional ability improved, and so he was able to walk with assistance, even though an ischemic focus developed in the spinal cord.

We present a case of a patient with cervical spinal cord ischemia who made an almost full recovery after having received combined treatment with thrombolysis and neurosurgery. In the available literature we have not found any description of a combined treatment with recombinant tissue plasminogen activator (rt-PA) and neurosurgery for myelopathy, and that is why we would like to share our experience.

\section{CASE REPORT}

On the $29^{\text {th }}$ of January, 2017, a 61-year-old right-handed male was admitted to the Department of Neurology with Stroke Unit as an emergency patient due to weakness in his right limbs, which had begun at $8 \mathrm{am}$ on the same day. The patient did not have a family history of cardiovascular diseases or any risk factors, and had done sports actively.

His previous history included cervical spine surgery at the C5-C6 level due to discopathy and spinal stenosis in 2010, as well as surgery for right-sided carpal tunnel syndrome in 2016. Despite the surgery for carpal tunnel syndrome, since September 2016 the patient referred paresthesias of fingers on the right-hand, in particular the fourth and fifth ones, most frequently after having worked with his right hand. An magnetic resonance imaging (MRI) showed an osteophyte and ossification of the posterior longitudinal ligament at the C5 level, as well as a narrowing of the spinal canal to $5 \mathrm{~mm}$ and ischemic lesions in the right anterior horn of the cervical spinal cord (Figure 1). The patient suffered from periodic neck pain, but it did not impede sporting activities (he played tennis once a week).

Apart from weakness in the right limbs, the patient referred neck pain, which was attributed to cervical spine lesions. Physical examination on admission revealed right-sided hemiparesis ( 3.5 Lovett scale), and there was no clear facial asymmetry observed. The patient was able to walk with assistance, his speech was normal and fluent, and he responded appropriately to questioning: 8 points

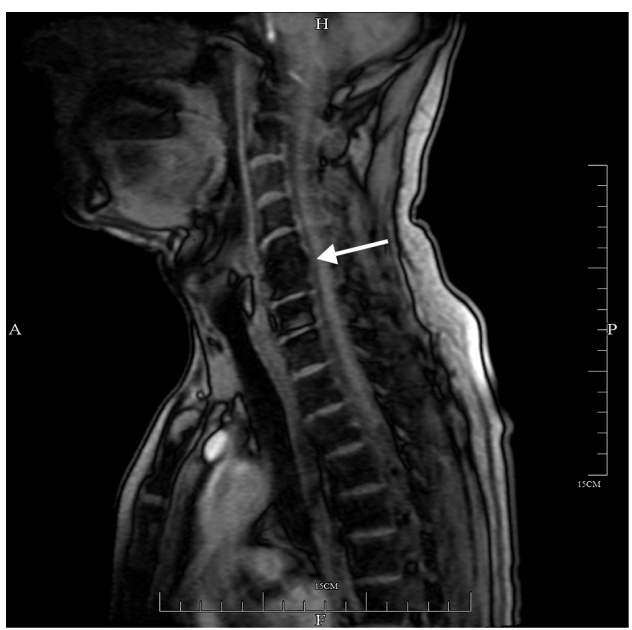

Figure I. Cervical spine MRI in 2016 - the arrow indicates an osteophyte at the C5/C6 level compressing the cervical spine cord (longitudinal cross-section) 
A

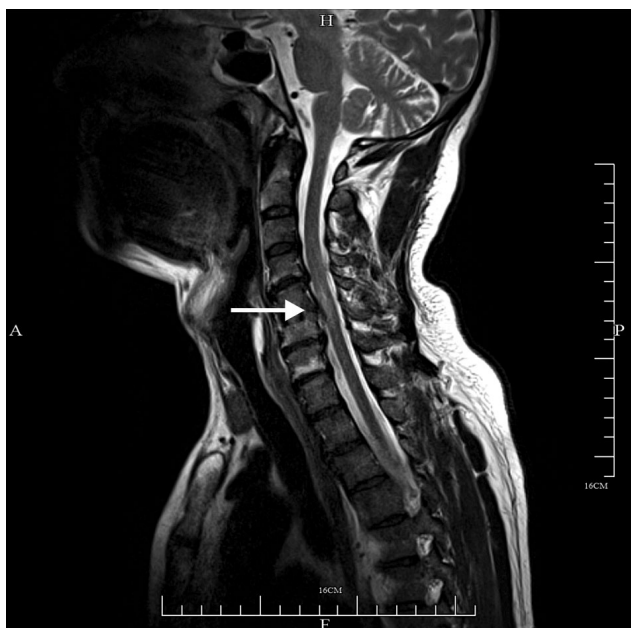

B

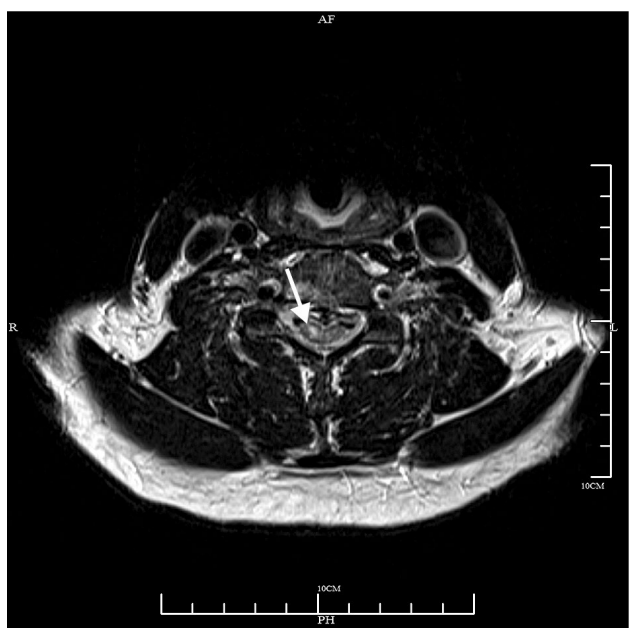

Figure II. A) Cervical MRI - longitudinal cross-section, compression of cervical spine at the C5/6 level and the narrowing of the spinal canal to $5 \mathrm{~mm}$. B) Transverse cross-section, ischemic lesions and oedema at the C5/6 level in the right anterior horn of the cervical spinal cord (an area vascularized through branches of the anterior spinal artery)

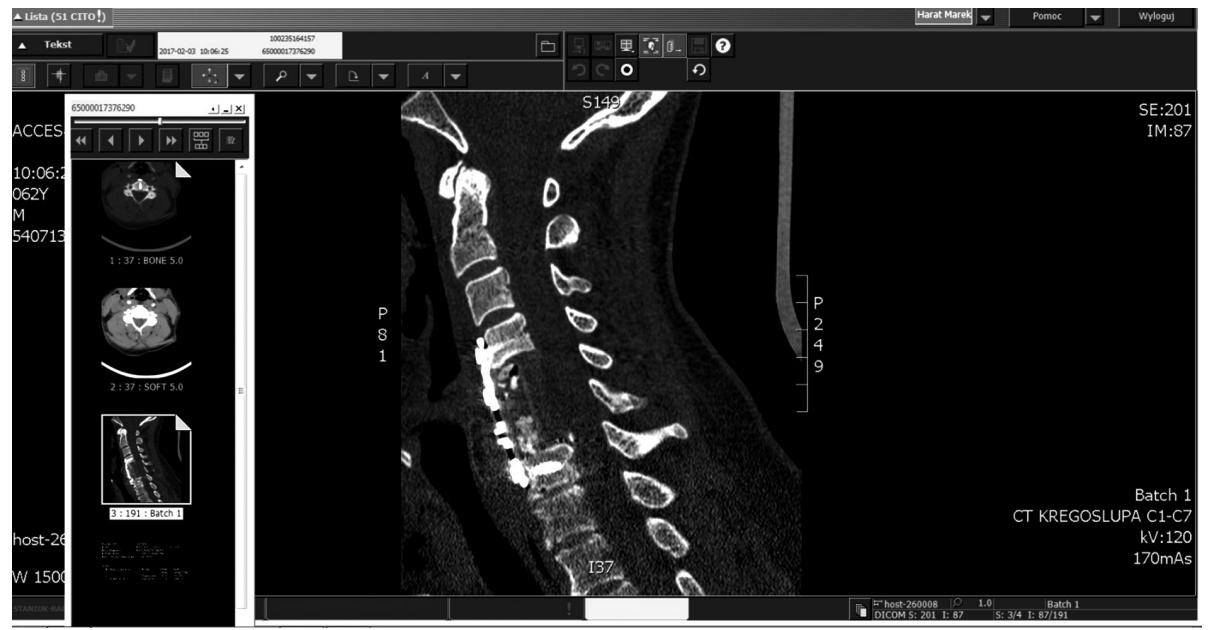

Figure III. CT after the surgery. Visible decompression of the spinal canal. Removed C5 and C6 vertebral bodies. In the place where the vertebral bodies were removed, visible prosthesis with bone chips, and anterior plate fixed with screws at the C4 and C7 level

on the National Institute Stroke scale (NIHSS), 3 points on the modified Rankin scale (mRs). Computed tomography $(\mathrm{CT})$ perfusion exposed neither blood circulation disorders nor other characteristics of a recent stroke. CT angiography of carotid and vertebral arteries did not reveal any pathology. Blood parameters (glucose level, coagulation test, morphology with plates) and ECG were normal. Recombinant tissue plasminogen activator was administered intravenously within 90 minutes of the onset of symptoms $(0.9 / \mathrm{kg} ; 10 \%$ in bolus, the rest via an hour long intravenous infusion). Immediately after the administration of the agent, the hemiparesis resolved completely and the patient was able to walk normally without assistance. Follow-up CT did not expose any ischemic lesions in the brain. On the night from the $29^{\text {th }}$ to the $30^{\text {th }}$ of January, 2017, he experienced increased neck pain, parestesis of both upper limbs with emphasis on the right side, and the following morning, weakness in the right limbs (3.5 on the Lovett scale). A brain MRI did not reveal any ischemic lesions, and an MRA showed normal vessels. A cervical spine MRI showed osteophyte/ossification in the posterior longitudinal ligament at the C5-C6 level compressing ventral surface of the spinal cord, and degenerative changes in the area of ligamenta flavia that support the cervical spine from the back. The anteroposterior diameter of the spinal canal was $5 \mathrm{~mm}$. At the C-6 level there were ischemic lesions and oedema visible in the right anterior horn of the cervical spinal cord (an area vascularised through branches of the anterior spinal artery) (Figure II). The patient received enoxaparin (sub- 
cutaneously), acetylsalicylicacid, atorvastatin, torasemide, ramipril, $24 \mathrm{mg}$ of dexaven (intravenously) and mannitol. He was under constant rehabilitation. The examination was followed by a neurosurgical consultation, and the patient was determined eligible for neurosurgical treatment. On the $1^{\text {st }}$ of February, 2017, the parestesis increased, and the patient began to walk with assistance. On the $2^{\text {nd }}$ of February, 2017, he received Solu Medrol intravenously, and underwent neurosurgery in the Department of Neurosurgery of the $10^{\text {th }}$ Military Research Hospital and Polyclinic in Bydgoszcz (Figure III). The surgery was followed by a rehabilitation treatment. The patient's condition was improving, and on the $22^{\text {nd }}$ of February, 2017, he was discharged from hospital. A month after the surgery the patient was able to walk quite quickly and without assistance, his gait mechanics were normal, the strength of the upper right limb and the right hand dexterity improved considerably - he made precise movements, and was able to write legibly and quite quickly. The patient resumed professional activity 3.5 months after the onset of symptoms.

\section{COMMENT}

We have presented the case of a patient with ischemic cervical myelopathy caused by the compression of degenerative osteophyte on the anterior spinal artery at the C5/6 level, which led to ischemia in the right anterior horn of the cervical spinal cord. It may be assumed that the compression on the anterior spinal artery had led to the formation of vascular thrombus. Thrombolysis with intravenous rt-PA probably dissolved the thrombus, and so the paresis resolved. Koch et al. have described an 81-year-old paraplegic patient with thoracic spinal cord ischemia who had been treated with intravenous rtPA within 3 h 40 min of the onset of symptoms. The follow-up MRI showed spinal cord infarction below thoracic segment 10 , however, the administration of thrombolysis decreased the paresis and the patient began to walk with assistance [8]. The authors have drawn attention to the fact that before the administration of rt-PA it is necessary to exclude aortal dissection and spinal tumour. On the other hand, Ringney et al. [3] have described eight patients with nontraumatic spinal cord infarction (SCI). In three patients, SCI was caused by aortic disease, including one patient with biopsy-confirmed giant cell arteritis. Fibrocartilaginous embolism was suspected in two other patients, anterior spinal artery aneurysm in one, and the cause was undetermined in two patients.
One of the patients died, two were wheelchair dependent, four walked with assistance, and just one was mobilising independently. None of the patients was treated with rt-PA [3]. The authors have emphasised that spinal cord infarction is a rare condition, and the prognosis is serious. A literature review [9] of 11 nontraumatic SCI patients showed that the patient's condition at the onset of symptoms is decisive for further prognosis: A/B ASIA scores strongly correlate with a poor outcome. However, those patient were not treated with thrombolysis. It seems that the condition of at least some of them could have been better had they received such treatment.

In the case of our patient, spinal ischemia was caused by mechanical compression of the anterior spinal artery by an osteophyte, and so intravenous thrombolysis turned out to be insufficient. Initially, the paresis resolved completely, however, it reappeared within 24 hours. Neurosurgery was necessary: the osteophyte was removed, and the anterior spinal artery was unblocked, thus allowing uninterrupted blood flow. The same dose of rt-PA was used in thrombolysis as in the case of ischemic stroke: $0.9 \mathrm{mg} / \mathrm{kg}$, similar to the proceedings of Koch et al. [8]. In our patient, the paresis resolved almost completely, which was possible due to the prompt administration of rt-PA (90 min from the onset of paresis) combined with an indispensable neurosurgical intervention.

We would like to draw attention to the fact that sudden limb paresis may be caused not only by stroke, but also by spinal cord ischemia, a less frequent condition [1]. It seems that intravenous thrombolysis can improve ischemic patients' condition, as proven by the case of the 81-year-old patient [8] as well as by that of our patient. However, if there is mechanical compression (e.g. degenerative osteophytes) on the spinal artery, thrombolysis is not sufficient the lesion must be removed immediately in a hospital with vast experience in such surgery.

Concluding - close cooperation between neurologist and neurosurgeron along with prompt and determined treatment turned out to be highly effective in the presented case of a patient with ischemic cervical myelopathy caused by the compression of osteophyte on the anterior spinal cord. In spinal cord ischemia, the administration of intravenous thrombolysis within an adequate time window (4.5 hours, as in the case of a stroke) may prevent permanent spinal cord dysfunction, and may be extremely useful before the scheduled neurosurgery, as was the case with our patient. It is recommended to set up a registry of patients with spinal cord ischemia that have been treated with rt-PA in order to evaluate the effectiveness of the treatment. 


\section{Conflict of interest/Konflikt interesu}

Absent./Nie występuje.

Financial support/Finansowanie

Absent./Nie występuje.

\section{References/Piśmiennicłwo}

1. Błażejewska-Hyżorek B, Członkowska A. Zaburzenia ukrwienia rdzenia kręgowego. W: Stępień A. Neurologia. Tom II. Warszawa: Medical Tribune Polska; 2014, p. 298-304.

2. Tubbs RS, Blouir MC, Romeo AK, Mortazavi MM, Cohen-Gadol AA. Spinal cord ischemia and atherosclerosis: a review of the literature. Br J Neurosurg 2011; 25: 666-670.

3. Rigney L, Cappelen-Smith C, Sebire D, Beran RG, Cordato D. Nontraumatic spinal cord ischaemic syndrome. J Clin Neurosci 2015; 22: 1544-1549.

4. Antelo MJG, Facal TL, Sanchez TP, et al. Man-in-the-Barrel. A case of cervical spinal cord infarction and review of the literature. The Open Neurology J 2013; 7: 7-10.

5. Arroyo HA. Acute non-traumatic myelopathy in children and adolescents. Rev Neurol 2013; 57 (Suppl 1): 129-138.

6. Arai S, Utsunomiya H, Wakugawa Y, Uwadoko T. A case of spinal cord infarction caused by cervical disc herniation. Brain Nerve 2007; 59: 997-1000.

7. Acker G, Schneider UC, Grozdanovic Z, Vajkoczy P, Woitzik J. Cervical disc herniation as a trigger for temporary cervical cord ischemia. J Spine Surg 2016; 2: 135-138.

8. Koch M, Prothmann S, Poppert H, Seifert CL. Systemic thrombolysis in anterior spinal artery syndrome: what has to be considered? J Thromb Thrombolysis 2016; 41: 511-513.

9. Reynolds JM, Belvadi YS, Kane AG, Poulopoulos M. Thoracic disc herniation leads to anterior spinal artery syndrome demonstrated by diffusion - weighted magnetic resonance imaging (DWI): a case report and literature review. Spine J 2014; 14: 17-22. 